\title{
A TANULÁSI MOTIVÁCIÓ FEJLESZTÉSÉNEK ÚJ LEHETŐSÉGEI
}

\section{Mester Dolli}

\author{
az Eszterházy Károly Főiskola \\ föiskolai adjunktusa \\ dollim@ektf.hu
}

\begin{abstract}
Tanulmányunkban a pszichológiai immunrendszer (Oláh, 2005) hatását vizsgáltuk a föiskolai hallgatók személyiségjegyeire vonatkozóan, melyek befolyásolhatják a tanulási motivációt, az iskolai eredményeket és a föiskolai tanulmányokkal kapcsolatos attitüdöket. Ezek a tényezők fontosak lehetnek az önszabályozó tanulás szempontjából is (Boekaerts, 1997). A kutatás az Eszterházy Károly Föiskolán zajlott. A pszichológiai immunrendszer olyan személyiségjegyek összessége, melyek képessé teszik az egyént a stresszhelyzetek kognitiv értékelésére, az adekvát megküzdési stratégiák megválasztására, a megküzdési folyamatokba bevonható források feltárására és alkalmazására, valamint az eredményes megküzdésre úgy, hogy a személy integritása, müködési hatékonysága fenntartható legyen. Az egyéni megküzdési képesség befolyásolja a tanulási motivációt (Printich et al., 1994), a problémahelyzetek kezelését, az én-hatékonyságot is, többek között.
\end{abstract}

A tanulás motiválása, a jobb eredmények elérésére való ösztönzés mindig fontos feladata volt a pedagógusoknak. Ezen belül is, kiemelten fontos feladatok a serdülö- és az ifjúkori korosztály motivációjának fejlesztése, hiszen ez az az életkor, amikor valóban egyre konkrétabb remények, célok és elvárások fogalmazódnak meg a fiatalok fejében a jövőjükkel kapcsolatban, ennek részeként pedig főként a családdal, az iskolai tanulmányokkal és a jövőbeni munkához kötődően jelennek meg olyan célkitüzések, melyek a későbbi felnőtt élet sikerességét is befolyásolják.

A tanulási motiváció megértése és hatékony fejlesztése céljából fontos a személyiség, a környezet, valamint a pedagógiai, pszichológiai, szociológiai és etikai hatásmechanizmusok együttes tanulmányozása (Nagy, 2000). Arra érdemes gondolni, hogy a tanuló önszabályozó folyamatainak részeként célszerü szemlélni a tanulási motivációt, mely a tanulót (metakognitív, metamotivációs és viselkedési szempontból) saját tanulási folyamatának aktív részesévé teszi (Réthy, 2003).

Kutatások bizonyítják, hogy a megélt önszabályozás pozitívan korrelál a belső motivációval, a kellemes emóciókkal és a metakognitív szabályozó folyamatokkal (Klaus, 1997, idézi Réthy, 2003; Csíkszentmihályi, 1992, idézi Réthy, 2003). Továbbá meg kell említeni a Ridley (1991) által leírt reflektív önszabályozás folyamatát is, mely során a tanuló fontos jellemzője, hogy egyre kevésbé függ a pillanatnyi külső körülményektöl. Mindig összeveti az őt érő külső hatásokat a korábban szerzett tapasztalatokkal, és a kapott értékelést akár felül is bírálhatja. Ez a fajta reflektív 
önszabályozás tehát az értelmi, motivációs, érzelmi és akarati tényezők egymásra hatásán alapul, és egyidejüleg befolyásolja az énkép alakulását is, ami aztán viszszahat az értelmi, motivációs érzelmi és akarati összetevőkre.

\section{A motiváció értelmezései és az integratív modell}

A diákok tanulásra való motiváltságát önmagában is nagyon sok tényező befolyásolhatja. A különböző elméleti irányzatok (behaviorizmus, kognitív és humanisztikus nézőpont) más-más okokat jelölnek meg arra vonatkozóan, hogy egyes tanulók egy adott tanulási szituációban miért akarnak jobban dolgozni mint mások, és ebből következően a motivációs eljárások kidolgozásának elvi alapjait is másban látják.

A behavioristák a kívánatos viselkedés megerősítését, a külső motiváció eredményességét hangsúlyozzák, mindemellett a szociális tanuláselméletek teoretikusai felhívják a figyelmet az utánzás, azonosulás fontosságára is. A kognitív motivációs felfogás szerint az emberek különböző módon észlelik az őket körülvevő világot, és ez befolyással bír viselkedésükre, magatartásukra. Eszerint az elméleti elképzelés szerint a tanulási, megismerési folyamatokban a belső motiváción van a hangsúly, és az egyén azért sajátít el dolgokat, mert a belső kognitív egyensúly felborulása, az ismeretekre vonatkozó hiányosságainak megtapasztalása erre készteti. A humanisztikus szemlélet képviselöi szerint az ember egyik legfontosabb jellemzője az önmegvalósítás mint belső törekvés, és ez a belső fejlődési igény készteti arra, hogy célokat tüzzön ki maga elé, és képességeit, erőforrásait latba vetve, mindent megtegyen ezen célok megvalósításáért.

Mindegyik nézőpontnak megvannak a maga korlátai, melyeket csak egy integratív megközelítés segítségével lehetett feloldani. A motiváció integratív, háromdimenziós modelljét Kozéki (1980) alkotta meg. Ez a modell egyszerre kívánja megragadni a pedagógiai hatásokat, a pszichológiai folyamatokat és a motivációs rendszer dinamikus struktúráját. A modell 3 dimenziót különít el egymástól:

- Az affektív dimenzió az emberekhez való viszonyulás késztetéseit tartalmazza. Főbb összetevői: a melegség (ami az érzelmi kapcsolatokat a dependenciától a gondoskodás ösztönzéséig terjedően foglalja magába), az identifikáció (mely az azonosulás és a hasonulás vágyát jelenti) és az affiliáció, a szociabilitás (mely a csoportba tartozás, a barátság, a közösségi érzés ösztönzését vizsgálja).

- A kognitiv dimenzió a feladathoz való viszonyulás késztetéseit tartalmazza. Főbb összetevői: az independencia (az autonómia, a függetlenség, a világban való önálló tájékozódás késztetése, a feladatnak való megfelelés és az önbizalom késztetése), a kompetencia (a tudásvágy, a hatékonyság vágya, a mesterségbeli tudás örömének elérésére irányuló késztetés) és az érdeklődés (ami tulajdonképpen az aktivitás öröme a játéktól a problémamegoldásig terjedően). 
- Az effektív dimenzió az embernek önmagához, mint társadalmi lényhez való viszonyát tükrözi. Főbb összetevői: a lelkiismeret (az énideálnak való megfelelés késztetése), a rendszükséglet (a környezet által való megbecsülés vágya) és a felelősség (a moralitásra, az egyéni értékrendszer és a társadalmi normarendszer közelítésére irányuló késztetés).

Ez a modell nem csak integratív nézőpontja miatt jelentős - írja Tóth László (2000) -, hanem azért is, mert az ennek alapján kidolgozott papír/ceruza módszer (Kozéki, 1986) jelentős segítséget nyújt a tanároknak a diákok iskolai motivációjának feltárásához.

\section{A teljesítménymotiváció}

A fent említett általános megközelítésen túl, tudjuk azt is, hogy nagy egyéni különbségek lehetnek a tanulással kapcsolatos motivációban, azaz a diákok különböző motiváltsággal mennek iskolába. Ezek a különbségek nagyrészt a tanulási folyamatban szerzett elözetes tapasztalatok eredményének köszönhetően alakultak ki. A kedvező tanulási tapasztalat önbizalmat épít, erősíti az önbecsülést. Az egyénnek pozitív önértékelése lesz, jövő-orientálttá válik, és mivel a kedvező tapasztalatok növelik a saját hatékonyságba vetett bizalmat, a személy mindig nehezebb feladatok felé mozdul, keresi a lehetőségeket, hogy erejét kipróbálja. A kedvezőtlen tanulási tapasztalat önbizalomhiányt, irreális célok kitüzését, negatív énképet, szorongást, kudarckerülést okoz.

A teljesítménymotiváció és a szorongás többszörösen összefügg egymással. Minden feladatot csak megfelelő aktivációs szinten lehet eredményesen megoldani. Mindenkinek van egy nagyjából állandónak tekinthető aktivációs szintje, valamint a különböző nehézségü feladatoknak különböző mértékü lehet a szorongás- és stresszkeltő hatása. Selye (1969) stresszel kapcsolatos kutatási tapasztalatai alapján elmondhatjuk, hogy a stressz egyik jellemző hatása, hogy beszükíti a gondolkodásunkat, nehezíti az emléknyomok memóriánkból történő előhívását, nehezebben fedezzük fel a különböző ok-okozati összefüggéseket, nehezebben asszociálunk, nehezebb a racionális gondolkodás, a logikus következtetések levonása. De az is igaz, hogy a kis mértékủ stressz serkentheti az agymüködésünket, lehet teljesítményfokozó hatása, $\mathrm{s}$ a fenti problémák nem jelentkeznek. Mindezeken túl a sikerhez, illetve a kudarchoz való viszony is befolyásolja az egyén magatartását, viselkedését, tevékenységét.

A tanulási feladathoz való viszonyulás alapján a tanulókat nagy általánosságban a sikerorientált és kudarckerülő csoportba sorolhatjuk. A sikerorientáltakra általában jellemzőbb egy erős törekvés a sikerességre, sok területen kitartóbbak és külső kontroll hiányában is jól teljesítenek. Önállóak, képesnek érzik magukat a problémahelyzetek megoldására, ha valamit nem sikerült megoldaniuk, akkor sem veszítik el motivációjukat, hanem újabb tervet készítenek a cél elérésére, és meg- 
próbálják erőforrásaikat kihasználva teljesíteni azokat. Mindezeken túl kíváncsiak, érdeklődők, bár szociális motívumaik alacsonyabb szinten vannak. Ezzel szemben a kudarckerülők kevésbé bíznak saját képességeikben, nagyobb mértékü teljesítményszorongás jellemzi őket, sokszor nem tudják megfelelően felmérni saját lehetőségeiket, így nem ismerik fel azok jelentőségét egy-egy probléma megoldásában. A nagyobb mértékü teljesítményszorongás következményeként a mentális egészség védelme érdekében vagy kilépnek a feladat helyzetböl, vagy leblokkolnak, a végeredmény pedig ismételten kudarc lesz.

A teljesítménymotivációval kapcsolatban mindenképpen meg kell említeni az igényszintet, mely először Kurt Levin munkájában jelenik meg. Az igényszint elvárások összességét jelenti, melyek egy jövőbeni teljesítményre vonatkoznak (Levin, 1935). Sikeres feladatmegoldás után általában az igényszint emelkedik, ismételt kudarc esetén pedig csökkenti az igényszintet az egyén, hogy elkerülje a sikertelenséggel együtt járó kellemetlen érzéseket.

\section{Szándék, akarat, megküzdés szerepe a motivációban}

A tanulás motivációs hátterének egyik másik fontos tényezője a szándék, akarat, mely lényeges előfeltétele a metakognitív késztetés fenntartásának és átvitelének is.

Kutatások sora bizonyította, hogy a diákokat tanulásuk során elsősorban élvezeti célok befolyásolják és csak ezután következnek a tanulási célok, alkalmazkodási célok, majd munkacélok. Ezek a célok sokszor nem egyeznek a tanárok elvárásaival, tanítási célkitüzéseivel. Azaz a diákok szándékai sokszor nem esnek egybe a tanárok által elvárt szándékokkal (Lemos, 1996; Boekaerts, 2002).

A siker nem veleszületett képességektől függ, hanem attól, hogy az egyén mennyire hajlandó bizonyos törekvésekre, más szóval mennyire hajlandó a kemény, kitartó munkára. A tanulók egyénre jellemző, általában konzisztens stratégiákat dolgoznak ki tanulásuk során annak érdekében, hogy a sikeres tanulási teljesítményhez forrásokat szerezzenek, vagy a meglévők elvesztését megakadályozzák. Ezek a megküzdési stratégiák nem azonosak az elhárító mechanizmusokkal, a megküzdési folyamatot maga a személyiség, valamint azok a környezeti hatások vezérlik, amelyek az aktuális helyzetben az egyént körülveszik, befolyásolják.

A megküzdés eredményességét az egyén pszichológiai immunrendszerének kialakulása, müködése jelzi. A pszichológiai immunrendszer olyan személyiségtényezők összessége, melyek képessé teszik az egyént a stresszhelyzetek kognitív értékelésére, a megküzdési stratégiák megválasztására, a megküzdési folyamatokba bevonható források feltárására és alkalmazására, az eredményes megküzdésre úgy, hogy a személy integritása, müködési hatékonysága ne sérüljön. Más szavakkal azok a személyiségjegyek, amelyek a stresszel szembeni védettséget szavatolják, integrált rendszert hoznak létre. Ezt nevezzük pszichológiai immunrendszernek (Oláh, 1996). Ezek a személyiségtényezők több területen mutatnak összefüggést a sikerorien- 
tációval, illetve hiányuk, alacsony müködési hatékonyságuk kudarckerülő személyiséget eredményezhet. A pszichológiai immunrendszer 3 alrendszerböl épül fel:

1. Monitorozó - megközelítő alrendszer: olyan személyiségtényezőket tartalmaz, melyek a leghatékonyabb megküzdési stratégiák aktiválásában vesznek részt (képessé tesz olyan lehetőségek észrevételére, amit mások nem képesek észrevenni). A fizikai, szociális környezet megismerésére, megértésére, kontrollálására, a lehetséges pozitív következmények megfigyelésére hangolja a megismerő rendszert.

2. Alkotó - végrehajtó alrendszer: ezek a személyiség tényezők képessé tesznek arra, hogy az egyre növekvő kihívásokat egyre magasabb szinten legyen képes ellátni a személyiség, azaz a nehezített alkalmazkodási helyzet körülményei megváltoztathatóak és ezek birtokában, az egyén igényeinek megfelelöen képes eljutni a választott célhoz.

3. Önregulációs alrendszer: a feladatban való elmélyülés, koncentrálás feltételei, a tartós figyelemirányítás, a tevékenységtől elvonó gondolatok, érzelmek megjelenésének lehetőségét kizáró személyiség tényezők tartoznak ide.

\section{A kutatás előzményei}

A tanulási motiváció, tanulási hatékonyság fejlesztésének egyik fontos, az Eszterházy Károly Főiskolán zajló kutatási vonala a Dávid Mária (2004) által kidolgozott csoportos tanácsadás módszerén alapuló tanulásfejlesztő csoportok hatékonyságának vizsgálata, mely igazolta, hogy föiskolai hallgatók eredményessége, kompetenciái fejleszthetőek tréning módszer segítségével. A csoport előnye az egyszemélyes fejlesztéshez képest, hogy a problémamegoldáson, a különféle stratégiák kipróbálásán túl a támogatás, az együttmúködés megtapasztalásán keresztül nemcsak a meglévő tanulási módszerek változtathatóak meg sikeresen, hanem az egyén megtanulhatja, hogy erőforrásként kamatoztassa más hallgatók ismereteit, tapasztalatait a saját tanulási eredményességének fokozására.

Saját kutatásunk másik forrása az a tapasztalat volt, hogy a felsőoktatásban tanuló hallgatók nagy hányada tanulási problémákkal küzd. Ezek a problémák sikertelenséghez vezetnek, ami jelentős érzelmi megterhelésnek teszi ki a diákokat, $\mathrm{s}$ ezt fokozhatja, hogy a felsőoktatás által diktált, az általános és középiskolai tanulástól jelentősen eltérő követelményekhez való alkalmazkodásban nem kapnak szakmai segítséget.

E problémákra reagálva a Dávid Mária által vezetett longitudinális empirikus kutatás részeként 1999 és 2003 között az egri Eszterházy Károly Főiskolán kiegészítő kutatást folytattunk. A kutatásban arra kerestük a választ, hogyan befolyásolják az egyének személyiségében rejlő problémák a tanulási motivációt, a teljesítménymotivációt, a tanulás sikerességét illetve sikertelenségét. A következőket feltételeztük: 
1. A sikerorientáltak és a kudarckerülők eltérő pszichés megküzdési módokat használnak, melyek azonosíthatóak és megmagyarázzák a két orientáció eltérő hatását a tanulási motivációra.

2. A sikerorientáció a reflektív önszabályozás képességén keresztül az önregulációs rendszerrel áll szoros kapcsolatban, de a másik két alrendszer is pozitívan befolyásolja. A kudarckerülés hátterében pedig az önreguláció, illetve a pszichés megküzdést biztosító stratégiák hiánya, elégtelen müködése húzódik meg.

3. Kimutathatóak nemi különbségek a pszicho-immunkompetencia kérdőív által meghatározható stratégák használatában.

4. Az iskolai motiváció dimenzióit befolyásolják a pszichés megküzdési stratégiák.

\section{A vizsgálati minta bemutatása}

A kutatást első és másodéves föiskolai hallgatók körében végeztük. Összesen 177 hallgató vállalta a kutatásban való részvételt, de közülük csak 166 hallgató adatait tudtuk elemzésre felhasználni, mivel a többiek nem vagy nagyon hiányosan küldték vissza a kérdőíveket, illetve nem jelentek meg az igényszint vizsgálaton. A statisztikai elemzésben csak azok adatait használtuk fel, akik kitöltöttek minden kérdőívet és részt vettek az igényszint vizsgálatban is.

Nemek szerinti megoszlás: $126(75,9 \%)$ nő és $40(24,1 \%)$ férfi hallgató vett részt a vizsgálatban. Életkor szempontjából mindannyian 19 és 23 év között voltak.

\section{A vizsgálat során használt módszerek}

A pszichés megküzdési módokat meghatározó személyiségjegyek vizsgálatára a Pszichológiai Immunrendszer Kérdöivet (PIK) használtuk (Oláh, 1996). Ennek 16 skálája van, minden skálába öt tétel tartozik, a vizsgálati személyek négyfokú skálán jelezhetik, milyen mértékben tartják jellemzőnek magukra nézve az egyes állításokat. A 16 skála a következő:

1. Pozitív gondolkodás, optimizmus

3. Kontrollképesség

5. Koherenciaérzés

7. Öntisztelet

9. Növekedésérzés

11. Rugalmasság, kihíváskeresés

13. Empátia, társas monitorozás képessége

15. Leleményesség
2. Én-hatékonyságérzés

4. Társas mobilizálás képessége

6. Szociális alkotóképesség

8. Szinkronképesség

10. Kitartás képessége

12. Impulzivitás kontroll

14. Érzelmi kontroll

16. Ingerlékenység gátlás 
A sikerorientáció és a kudarckerülő személyiség dimenziók elkülönítésére az igényszint próbát használtuk, mely eredményeinek értékelésénél négy mutatót vettünk figyelembe:

- Célkülönbség: az adott teljesítmény és a rákövetkező vállalás különbsége.

- Az első vállalás: az az érték, melyet a vizsgálati személy találomra, előzetes teljesítmény nélkül, csak egy csavar kipróbálása után mond (10-15 között).

- A teljesítmény: az öt teljesítmény átlagát számoljuk, és az első és az utolsó teljesítmény közötti különbséget vesszük.

- Az igényszint változása: a vsz. sikere általában emeli, kudarca csökkenti a vállalásokat.

Az első vállalás, a célkülönbség, az átlagteljesítmény és az igényszint változásának figyelembe vételével három csoportot különítettünk el általában:

- Ambiciózus csoport: az első vállalás átlaga a reális értékek zónáján belül, de annak felső határán van (15), magas a célkülönbség (+4 -5), a teljesítményátlag (13-14 vagy nagyobb), és a teljesítménynövekedés itt a legmagasabb (3-4).

- Ambíció nélküli csoport: az első vállalás alacsony, de reális (10), alacsony a célkülönbség $(-2-+2)$, alacsony átlagteljesítmény, ami a frusztráció elkerülését, könnyebb sikervárást, a vsz. kudarc esetén az egyszer már elért teljesítményhez sem ragaszkodik.

- Irreális csoport: az első vállalás 20 felett vagy 5 alatt, igen magas, vagy igen alacsony célkülönbség (10!), a meg sem közelített célhoz való merev ragaszkodás, verbálisan emeli a szintet, de a teljesítmény nem nö.

A tanulással kapcsolatos motiváció vizsgálatára a Kozéki (1986) által kidolgozott „Iskolai motiváció” kérdőívet használtuk. E kérdőíves módszer segítségével a fentebb bemutatott dimenziókat (affektív, kognitív, effektív) lehet vizsgálni. Dimenziónként három-három motívumcsoport és tizedikként a presszióérzést megragadó kategória tárható fel. A kérdőív 60 kérdésből áll és minden azonos számjegyre végződő tétel (pl. 1,11,21,31,41,51) egy adott skálába tartozik.

A dimenziók:

a) affektív dimenzió: melegség (M1), identifikáció (M2), affiliáció (M3),

b) kognitív dimenzió: independencia (M4), kompetencia (M5), érdeklődés (M6),

c) effektív dimenzió: lelkiismeret (M7), rendszükséglet (M8), felelősség (M9),

d) kiegészítő presszióérzés (M10). 


\section{A vizsgálat eredményei}

\section{A sikerorientáció, a kudarckerülés és a pszicho-immunkompetencia kapcsolata}

Az igényszint próba segítségével elkülöníthetó csoportokból az ambiciózus csoport alkotta a sikerorientáltak csoportját, az ambíció nélküli és az irreális csoportok pedig a kudarckerülők csoportját. A sikerorientált és kudarckerülő dimenziót összevetve a pszichológiai immunrendszer skáláiban szignifikáns eltérést a koherencia $(t=3,539 ; \mathrm{df}=164 ; \mathrm{p} \leq .038)$, a növekedésérzés $(\mathrm{t}=2,156 ; \mathrm{df}=164 ; \mathrm{p} \leq .033)$ és a szinkronképesség $(\mathrm{t}=3,539 ; \mathrm{df}=164 ; \mathrm{p} \leq .001)$ tekintetében találtunk. Tehát a sikerorientáltak:

- Képesek kihívásnak tekinteni a feladathelyzetet, hisznek abban, hogy a dolgok úgy alakulnak, ahogyan az ésszerüen elvárható, nem elmenekülnek, hanem szembenéznek a konfliktussal, a nehéz helyzetben is annak értelmét keresik.

- Büszkék elért eredményeikre, sikereiket fejlődésnek élik meg.

- Képesek odafigyelni, összpontosítani a feladatra, tudatuk, figyelmük feletti kontroll képessége megvan.

A sikerorientált - kudarckerülő személyek különböznek egymástól a Monitorozó - megközelítő alrendszerben is $(\mathrm{t}=1,906 ; \mathrm{df}=164 ; \mathrm{p} \leq .058)$. Azaz a sikerorientáltak inkább birtokában vannak a fizikai és a szociális környezet megismerése, megértése, kontrollálása képességének. Optimisták, koherenciaérzékkel, magas kontrollképességgel (meg vannak arról győződve, hogy a dolgok rajtuk múlnak, eröfeszítéseket tesznek a kontroll megszerzésére és megőrzésére) rendelkező, kihíváskereső személyek.

A tanulmányi átlagokat összehasonlítva, szintén a sikerorientáltak átlaga jobb $(3,72)$ volt, a kudarckerülőkénél $(3,59)$. Ezekből az adatokból természetesen meszszemenő következtetéseket nem lehet levonni, hiszen a tanulmányi átlagot több tényező befolyásolja (hány kollokvium, szigorlat volt abban a félévben, eltérőek lehetnek a szakátlagok is stb.).

Még egy eredmény, ami nem meglepő: a tanulmányi átlag a szinkronképességgel ( $\left.\mathrm{r}=.197^{*} ; \mathrm{p} \leq .011\right)$ és a kitartással $\left(\mathrm{r}=.169^{*} ; \mathrm{p} \leq .030\right)$ korrelációt mutatott. Ha tudom figyelmemet az előttem álló feladatra összepontosítani, képes vagyok a keletkező akadályok ellenére is folytatni a munkát, esetleges személyes szükségleteimet háttérbe szorítani, akkor az pozitívan fog hatni az eredményeimre.

Tehát az első hipotézissel kapcsolatban igazolódott, hogy a vizsgált mintánkban a sikerorientáltak és a kudarckerülő személyek eltérő pszichés megküzdési módokat használnak, és ez hatást gyakorol a tanulási motivációjukra is. A második hipotézis részben nyert igazolást, hiszen csak a Monitorozó alrendszer esetében sikerült különbséget kimutatni a sikerorientált és a kudarckerülő személyeknél. 
Nemi különbségek a psziho-immunrendszer megküzdési stratégiáinak használatában

A fiúk-lányok csoportját összehasonlítva az öntisztelet $(\mathrm{t}=3,698 ; \mathrm{df}=164 ; \mathrm{p} \leq .00)$, én-hatékonyság ( $\mathrm{t}=1,876 ; \mathrm{df}=164 ; \mathrm{p} \leq .05)$, szinkronképesség $(\mathrm{t}=2,073 ; \mathrm{df}=164 ; \mathrm{p} \leq .04)$ és a kitartás képességében $(\mathrm{t}=2,109 ; \mathrm{df}=164 ; \mathrm{p} \leq .036)$ találtunk szignifikáns különbséget a két csoport között. A fiúk ezek szerint magasabb önértékeléssel rendelkeznek, büszkébbek az elért eredményeikre, meg vannak arról győződve, hogy képesek azokra a viselkedésformákra, melyek a kitüzött cél eléréséhez szükségesek, és inkább képesek arra, hogy az akadályok ellenére is folytassák az elhatározott viselkedést. Mindezek mellett magasabb a frusztrációs toleranciájuk és a feszültségtürő képességük. Ezek a képességek segíthetik őket abban, hogy a feladataikat minél hatékonyabban oldják meg.

Az alrendszerek esetében az alkotó-végrehajtó alrendszernél $(\mathrm{t}=1,678 ; \mathrm{df}=164$; $\mathrm{p} \leq$.096) találtunk eltéréséket, bár itt a különbség nem szignifikáns. A fiúk hatékonyabban tudják a növekvő kihívásokhoz igazítani a megküzdési módot, azaz a fizikai és a szociális környezet, valamint akár önmaga megváltoztatásán keresztül is elérni a kitüzött célt. Leleményesebbek, kreatívabbak tudnak lenni, jó problémamegoldó képességgel, magasabb önértékeléssel rendelkeznek, és ha kell, képesek meggyőzni, maguk mellé állítani a többieket. Ebben segítheti őket esetleg jó kapcsolatteremtő képességük. Mind fizikai, mind szociális környezetük erőforrásait ki tudják használni, ha arra van szükség, vagy ha saját erőfeszítéseik kevésnek bizonyulnak. Ezeknek köszönhetően sikeresebbek lehetnek a tanulmányaikban.

Tehát igazolást nyer harmadik hipotézisünk, miszerint a kutatásban részt vevők között kimutathatóak nemi különbségek a pszichés megküzdési módok használatában.

\section{Az iskolai motiváció és a pszicho-immunkompetencia kapcsolata}

A melegség, a gondoskodás szükséglete fordítottan korrelál a növekedésérzéssel $\left(\mathrm{r}=-.156^{*} \mathrm{p} \leq .046\right)$, az identifikáció késztetése $\left(\mathrm{r}=-.157^{*} ; \mathrm{p} \leq .044\right)$ és az affiliáció $\left(\mathrm{r}=-.164^{*} ; \mathrm{p} \leq .035\right)$, a koherencia érzéssel, az independencia késztetése a növekedésérzésével $\left(\mathrm{r}=-.183^{*} ; \mathrm{p} \leq .036\right)$, társas monitorozással $\left(\mathrm{r}=-.213^{* *} ; \mathrm{p} \leq .006\right)$ és a leleményességgel $\left(\mathrm{r}=-.159^{*} ; \mathrm{p} \leq .041\right)$, a kompetencia, tudásszerzés szükséglete az énhatékonysággal $\left(\mathrm{r}=-.155^{*} ; \mathrm{p} \leq .047\right)$, az érdeklődés a szinkronképességgel $\left(\mathrm{r}=-.167^{*} ; \mathrm{p} \leq .033\right)$, a lelkiismeret, az önértékelés szükséglete a kontrollképességgel $(\mathrm{r}=-.172 * ; \mathrm{p} \leq .028)$, a rendszükséglet a leleményességgel $(\mathrm{r}=.169 * ; \mathrm{p} \leq .031)$ mutat korrelációt, de pozitív irányban.

A három dimenzió közül, a kognitív dimenzió mutatott fordított korrelációt az önregulációs alrendszerrel $\left(\mathrm{r}=-.157^{*} ; \mathrm{p} \leq .044\right)$

Mindezek alapján elmondható, ha az egyén úgy észleli, hogy képes megragadni az összefüggéseket és a dolgok az ésszerüségnek megfelelően fognak alakulni, 
akkor kezelni tudja és kihívásnak tekinti a nehéz helyzeteket is, és ezzel kivívhatja a tanárok, valamint a kortársak elfogadását.

$\mathrm{Az}$ independencia szükségletének kielégítésében segítheti a kellő mértékü leleményessége, kreativitása, valamint az a várakozása, hogy a kihívásoktól nem félni kell, hanem le kell azokat küzdeni. Amennyiben erre nem képes, akkor meg fog hátrálni a feladatok elől, s a kudarckerülési stratégiákat helyezi előtérbe. Az autonóm ember saját útját járja és ehhez képes támogatókat keresni, kiaknázni mindazt, ami másokban rejlik. Ha a diák bízik saját magában, belső meggyőződése, hogy céljait képes megvalósítani, akkor nagyobb esélye van arra, hogy a kompetenciakésztetése is kielégítést nyer.

A problémákkal való aktív megküzdésben segítségére lehet a szinkronképesség, melynek lényege, hogy amennyiben szükség van rá, az egyén mindent megtesz, hogy összes pszichés energiáját a feladatra, annak megoldására összpontosítsa.

Ha képes a külső és a belső történések feletti kontroll gyakorlására, akkor energiáit és tevékenységeit képes lesz az énideáljához igazítani, olyan stratégiákat dolgoz ki és használ, melyek megfelelnek a társadalmilag meghatározott és saját maga által kívánatosnak tartott énje megnyilvánulásainak, müködésének.

Továbbá, amennyiben fel tudja találni magát bizonyos helyzetekben, bármenynyire is szorongatóak azok, ha azzal a meggyőződéssel bír, hogy bárhogy is alakulnak körülményei, szükség esetén rá fog jönni arra, hogyan fordíthatná jóra az adott szituációt, akkor annál inkább képes lesz a közösség levárásainak is megfelelni, képes lesz azokat az értékeket követni, melyeket elvárnak tőle.

Tehát negyedik hipotézisünk igazolást nyert, miszerint a különböző pszichés megküzdési módok hatással vannak az iskolai motiváció alakulására.

\section{Következtetések}

A kutatási eredmények arra ösztönöztek bennünket, hogy újragondoljuk a tanárképzési tartalmakat és azokat a megoldásmódokat, amelyek lehetőségeket teremtenek a hallgatók számára, hogy erősítsék, fejlesszék a pszichés megküzdő képességeiket, annak érdekében, hogy könnyebben meg tudjanak birkózni a tanulás és a növekvő terhelés következtében rájuk nehezedő nyomással. Olyan megnövekedett stresszel teli időszakokban is jól, vagy jobban tudjanak teljesíteni, mint amilyen a vizsgaidőszak. A fejlesztés ösztönzésében, támogatásában nagy szerepet tulajdonítunk a kooperatív tanulásszervezésnek és az önálló tanulást segítő módszereknek. Úgy véljük, ha hozzásegítjük őket ezen pszichés stratégiák kiépítéséhez, akkor nemcsak a tanulási, hanem minden olyan szituációt eredményesebben tudnak majd kezelni, amelyet korábban inkább szorongatónak, félelemmel telinek, megoldhatatlannak tartottak. 


\section{Irodalom}

Balogh László (2000): Tanulási stratégiák és stílusok, a fejlesztés pszichológiai alapjai. Kossuth Egyetemi Kiadó, Debrecen.

Boekaerts, M. (1997): Self-regulated Learning: A New Concept Embraced by Researchers, Policy Makers. Educators, Teachers and Students. Learning and Instruction, 2. sz. 161-186.

Dávid Mária (2004): Tanulási hatékonyság fejlesztése a felsőoktatásban csoportos tanácsadás módszerével. Doktori értekezés. Debreceni Egyetem, Bölcsészettudományi Kar, Debrecen.

Kozéki Béla (1980): A motiválás és motiváció összefüggéseinek pedagógiai pszichológiai vizsgálata. Akadémia Kiadó, Budapest.

Lemos, M. S. (1996): Students' and teachers' goals in the classroom. Learning and Instruction, 6, 2, 151-171.

Lewin, K. (1935): A dynamic theory of personality. New York: McGraw-Hill.

Nagy József (2000): XXI. század és nevelés. Osiris Kiadó, Budapest.

Oláh Attila (1996): A megküzdés személyiségtényezői. Kandidátusi értekezés. ELTE BTK.

Oláh Attila (2005): Anxiety, Coping, and Flow: Empirical studies in interactional perspective. Trefort Kiadó, Budapest.

Printich, P. R., Garcia, T., de Groot (1994): Motivational an selfregulated learning componets of classroom academic performance. Journal of Educational Psychology, 82. sz. 33-40.

Réthy Endréné (1999): Motiváció: felfogások, elképzelések, hitek. Iskolakultúra, 9. sz. 56-59.

Réthy Endréné (2003): Motiváció, tanulás, tanitás. Miért tanulunk jól vagy rosszul. Nemzeti Tankönyvkiadó, Budapest.

Ridley, D. S. (1991): Reflective Self-Awerennes: A Basic Motivational Process. The Journal of Experimental Education, 60, 1, 31-48.

Selye J. (1969): Életünk és a stress. Akadémiai Kiadó, Budapest.

Tóth László (2000): Pszichológia a tanitásban. Pedellus Tankönyvkiadó, Debrecen. 